\title{
Sciendo
}

\section{Intractable Pernicious Practices in West Africa}

\author{
AKPOJEVBE OMASANJUWA \\ Geography Unit \\ University of the Gambia, Serre Kunda, Gambia \\ masapele@yahoo.com
}

\begin{abstract}
Spiteful practices such as human sacrifice and cannibalism have endured the abhorrence of various peoples of the world. However, European powers magnified the proportion of these activities in other parts of the world to justify their colonial agenda of subjugation and exploitation, while they equally partook of it in various shades at different times in their history. This paper, focused on West Africa, explains both the motives fuelling the intractable problems and the obstacles encysting their elimination. Although some solutions were proffered, the ingrained problem will continue to resist change.
\end{abstract}

KEY WORDS: athropophagy, cannibalism, ritual murder, human sacrifice, West Africa

European colonial administrators did not mask their repugnance to a number of practices during their 'civilising' mission in Africa. In addition, their attempts to rationalise the cultural settings in which they were serving were marred with prejudice. This undoubtedly prompted Philip Curtin to postulate that European images of Africa were more European than African (LAW 1985:63). They could neither fathom nor bother to comprehend the nature of these practices. An assortment of activities that were categorised by the administrators, missionaries, traders, and other Europeans as human sacrifice and allied practices span across a spectrum with blurred demarcations. Hence, addressing matters of this nature is essential, 
as Forbes noted that western anthropologists and historians usually stop talking about human sacrifice the moment they shift their gaze from non-Western to Euro-Western societies (FORBES 1995:60).

The author of this article has the experience of visiting a West African country in 2009, a country he last went to in almost two decades. His elderly friend in the country became an ancestor over ten years before the visit. As a mark of respect, he, in the company of the deceased's grandchild went to the grave site to pay his respects and rekindle his memory of his departed friend. He, however, observed that there were numerous potholes in the cemetery. What flashed across his mind was a practice, akin to ablution, performed by some indigenous South Africans. When they return from a burial ground, they customarily wash their hands with water before entering their houses. Out of curiosity, he inquired to ascertain why there were many of such hollows in the graveyard, as he thought that they might be spots where mourners washed their hands before departure. He was dead wrong. To his consternation, he learnt that they were among graves desecrated nationwide. Marauders dug up the corpses nocturnally to cut off essential parts with which they concoct ritual medicines. The discovery could be an infinitesimal fraction of repugnant practices that has stood the test of time, part of the abysmal secrets of the ancients that include cannibalism, human sacrifice, and ritual murder.

Comparable to the author's experience, in April 1996, the city of Monrovia, Liberia was under an unprecedented military siege as belligerent factions, during the Liberia Civil War, vied for its control. Consequently, dead bodies littered the streets and other public arenas. On the bodies were assorted amulets tied on them to make their carriers bulletproof. People were amazed on seeing soldiers and even civilians reaping the corpses open and devouring the flesh and organs, the heart being the choicest. This they did with the notion that consuming the parts of a warrior would enable the consumer acquire the valour of the victim. Some told reporters that "to eat the heart of a strong man makes us strong too" (ELLIS 2001: 222). ${ }^{1}$ As the war abated, the interim President of the republic, Gyude Bryant, in 2005 warned all and sundry that anyone convicted of ritual murder would face the wrath of the law, as he will not hesitate to append his signature on such death warrants. He took the stand, as rumours were rife that politicians were committing murder with the motive of concocting ritual medicines

In the Aztec cannibal culture, it is believed that the eater could absorb the virtues of the eaten.

DOI: 10.2478/eas-2018-0008 C University of SS. Cyril and Methodius in Trnava. All rights reserved. 
with the body parts of their victims. They are of the notion that it would secure them victory in a forthcoming election.

Dearth of information on undertakings of this nature has made it difficult to address, as they are secrets of countless generations that might never fully penetrate public domain. Investigators, like the police, who have attempted to probe the issues, rely on scientific methods in deciphering unscientific beliefs and practices. Besides, such efforts often end in fiasco due to the interference and involvement of influential members of society. The drudgery of addressing problems of this nature should not be the monopoly of social anthropologists. For this reason, this paper aims at unveiling the motives fuelling these pernicious habits in West Africa against the backdrop of similar habits elsewhere. Additionally, the reader will appreciate why, despite already expended efforts, the elimination of the repugnant practices is not in sight, contrary to the wishes of the populace.

The word cannibal is a legacy of Christopher Columbus's second voyage to the Caribbean in $1493 \mathrm{He}$ referred to the Caribs of the Antilles as eaters of human flesh. The word subsequently extended to flesh eaters of other populations (LINDENBAUM 2004: 477). In man, there are varieties of circumstances as there are motives for cannibalism. Any animal or person that consumes any individual of its own kind is a cannibal. Auto-cannibalism is the consumption of cast-off parts of oneself, e.g. hair, nail clippings, placenta etc. in most cases, under duress. Gustatory cannibalism is the satisfaction of one's craving for food through the consumption of human flesh while Epicurean cannibalism is when the consumer equates the victim less than human and therefore treats its flesh as a delicacy. Warfare cannibalism is a final act of annihilating one's enemy, especially war victims, as the reduction of the enemy to faeces is the ultimate humiliation. In exceptional cases, there is survival cannibalism when the will to survive compels one to consume human flesh, especially during starvation. Ritual cannibalism is a product of beliefs and religion, while pathological cannibalism results from cases of mental disorder. Mortuary cannibalism is the consumption of the remains of a family member, normally done as a mark of affection for the deceased.

Therefore, the practice could be either exo- or endo-cannibalism depending on the relationship of the consumed to the eater. For a detailed account of the different forms of the practice (see LINDENBAUM 2004). Cannibalism prevails in other species as a means of population control, a mark of strength in territorial control, and as a source of food. Conversely, human sacrifice is the killing of people in order to secure the favours of supernatural beings (LAW 1985:58). Both practices, though not identical, in some parts of South America, some anthropologists believe that portions of those offered for sacrifice are consumed as well. However, in West Africa, in almost all the places where the practices are 
allegedly prevalent, victims were either buried or left to decompose in the open air, especially those who tradition denied burial rites. They were not consumed.

\section{Spatial distribution}

Records overflow of nations and peoples who have allegedly been engaged in human sacrifice and related practices, especially cannibalism. "Research has led to the conclusion that the behavioural possibility or potentiality of cannibalism is entertained in all cultures... we have yet to encounter any case of a people bereft of a locally etched understanding of Anthropophagy" noted Isaac (ISAAC 2002:203). There are contentions that the Maori of New Zealand, the peoples of Polynesia and Melanesia (especially Fiji), Sumatra, and Papua New Guinea at various times had a taste of these practices. However, some degree of caution is essential, as there seems to be some manipulation of native stereotypes of savage cannibalism against indigenous people of this part of the globe by European colonizers, Katherine Biber noted (BIBER 2005:623). British colonial administrators in India abrogated the practice of widows voluntarily setting themselves ablaze during their husband's funeral. ${ }^{2}$ From diverse accounts, they purportedly sacrificed an unrivalled number of victims, 20,000 annually being the most commonly quoted figure. Harner lamented the silence of cultural evolutionists when it comes to explaining the remarkable and central part of Aztec civilization (HARNER 1977:117, 131). For detailed explanations of Aztec institutionalised cannibalism (see WINKELMAN 1998; GRAULICH 2000).

Turner and Turner (1992), Goldman (1999) and Brady (1982) demonstrated a renewed vigour in researching cannibalism when Arens (1979) impertinently insinuated that institutionalised cannibalism never existed because past reports about it were not based on credible eyewitness accounts (see BRADY 1982:595-561). Other ethnographers fiercely disapproved of Arens' opinion as, for example, the 17-century Iroquois of North America relished cannibalism to the extent of regarding it as a religious fervour meant to ensure success in war. Abler's (1980) stand on the matter is that ethnographers and other social historians should have an obligation to present the truth albeit without exaggeration and sensationalism.

2 For a detail account of the origin of the Balinese custom of sacrificing women at cremation ceremonies (see KRAAN 1985).

DOI: 10.2478/eas-2018-0008 C University of SS. Cyril and Methodius in Trnava. All rights reserved. 
He added that there was no point in suppressing facts by not having ones, ugly past published (see BINFORD 1981; VILLA 1992; WHITE 1992; TURNER - TURNER 1992).

\section{West African situation}

Robin Law's exposition is that in Africa, European observers undoubtedly through ignorance often interpreted as human sacrifice, killings as judicial executions, witchcraft ordeals and even political terrorism (LAW 1985:60). While Conklin wrote in the same vein with regard to the Wari ethnic group of the Brazilian Amazon by asserting that "negative representation of native people as cannibals served as tools of domination, providing moral legitimacy for government officials, entrepreneurs, missionaries and others who promoted self-serving images of savage natives to justify their subjugation" (CONKLIN 1997:68). During the colonial era on the Pacific front, there were "narratives of native savage become particularly important at moments on the frontier when tensions arose between the coloniser and the colonised. At this point, the narratives supplied the justification for force, violence, and domination.' Biber explained that "... It is important to establish from the onset that there is no credible historical evidence to support allegations that indigenous Australians practised the forms of cannibalism sought by colonialists. '.. in the dispassionate language of law reporting, the cold-blooded and wrong reasoned killing of a black man by a white man was dismissed smoothly and unconditionally by the shared belief that the natives ate white people' (BIBER 2005:625).

In 1503, Queen Isabella of Spain permitted enslavement of American Indians identified as cannibals (WHITEHEAD 1984:70). Equally, in 1510 Pope Innocent IV passed an ecclesiastical order declaring cannibalism a sin that deserved retribution by Christians with the force of arms. Hence, "in the conquest of South America, cannibalism provided perhaps the most potent weapon for European control" (WHITEHEAD 1984:72)." It is therefore not astonishing that during the colonial era, in line with practices in other parts of the world, Europeans used cannibalism as an additional weapon in their arsenal. They put it to use while portraying Africans as inferior members of the human race, thereby gaining ground to interfere into their internal affairs. This they did with the intension of absolving themselves of the possible indictment of invasion and genocide during the African colonial wars. Katherine Biber equally asserted that 'the accusation of anthropophagy by the colonialists 
functioned as a thinly-veiled disguise for British anthropophagous practices that flourished as a maritime culture developed in the age of imperial expansion' (BIBER 2005:637).

Accusations of ritual murder and similar practices undoubtedly undermined the reputation of Africans largely due to European deliberate misunderstanding of the cultural landscape of the continent. Granted that there were cases of 'ritual' murder and cannibalism and other associated practices, that does not justify colonial domination, as they were not unique to Africa besides, Africans equally demonstrated their repugnance to these practices, particularly cannibalism. The colonising powers at some time in the past, (even at present), were engaged in the same practices in different shades. Problems posed by these acts have remained intractable even after colonialism despite the wish of the populace in Africa to have them confined to antiquity.

European accounts exaggerated the gravity of the problem going by of their experiences in the sub-region. The Ashanti, Benin, and Dahomey Empires, as well as Calabar, and the area once referred to as Upper Guinea ${ }^{3}$ were prominent places associated with the practices. Except for Upper Guinea where, going by recorded accounts, cannibalism was prevalent, others were cases of human sacrifice. European administrators and missionaries in particular evaluated the issue of human sacrifice on a Western scale of values, thereby deliberately failing to acknowledge the sharply contrasting differences between African and European burial customs (see THOMAS 1920:379-380 and GRAHAM 1965:330). They could not also comprehend why Africans share the same belief as Christians that without the shedding of blood, be it animal or human, there can be no forgiveness of sins. ${ }^{4}$ The account of Whitehouse $(1905)^{5}$ centred on the alleged practice of human sacrifice and cannibalism. He narrated how he personally set a shrine on fire in his effort to stamp out the practices among the people of Allabia in the mangrove swamps of what is presently Southern Nigeria. There was no iota of cannibalism in his write-up. Though there were human skulls in the shrine, he did not explain if they were those of executed condemned criminals or witches and wizards, traditionally regarded as the very worst of criminals. Moreover, it is noteworthy that he should be indebted to a local informant who brought the issue to his attention. Ellis indicated that indigenous ideas of what constitutes evil or proper and improper use of violence were

3 Sierra Leone, Liberia and Ivory Coast.

$4 \quad$ Sacrifices and offerings are an integral part of Jewish tradition as attested to by accounts in both the old and new testaments of the Holy Bible.

$5 \quad$ Probably a District Officer. 
quite different from the views of missionaries whose vision of Africa regarded everything African as evil and diabolical (ELLIS 2001:228).

The various versions of events given about the aforementioned places were either contradictory or in most cases blown out of proportion, inconsistent, and portrayed European resolve to be deliberately ignorant of the cultural landscape of the indigenous African peoples (see WILLIAMS 1988; WILKS 1988 and GRAHAM 1965). Graham, for example, explained that during the funeral and interment of the $O b a$ (King) of Benin, his principal favourites count it an esteemed honour to be interred with him. This can be interpreted as cases of men who died appreciatively. Tradition demands that an entourage of aides, in a number befitting their status, should accompany dead Obas into the spirit realm. Most of such victims were condemned criminals on death row and prisoners who have been reconciled to their death (GRAHAM 1965:328).

During ceremonies, particularly those that were annual, and when prayers for rain in years of drought failed (similar to the Aztecs and Incas of South America), human sacrifices were performed. The executed are often condemned prisoners and persons who died from infectious diseases to whom traditions deny decent burial. The most abhorrent to European idea was the sun and rain sacrifice in which victims were fastened to tree branches, most of whom were witches and wizards who have been adjudged guilty also in the court of public opinion as they were classed among the worst of criminals. Also, erroneously ranked among human sacrifice was the trial of suspected witches and wizards by the administration of poison. This was a widespread scene as society sees them as undesirables. This was a judicial punishment (LAW 1985: 58-59).

\section{Sierra Leone in the spotlight}

In Upper Guinea, the inability of European administrators to differentiate the functions of the Poro Society from the activities of criminal organisations or associations such as The Human Leopards Society generated intractable problems, a limitation born out of prejudice and fear as secret orders in the West invoke some degree of fright. The Poro society happened to be the most prominent of the secret fraternities prevalent in the area, comparable to any western secret order, yet perceived by the government as being subversive to foreign rule. Little stated that collectively, Sierra Leone secret societies provide an institutional structure that bears resemblance to the medieval church in England (LITTLE 1949:199). "The purpose of the society was partly religious, partly educational, and partly concerned with the regulations of 
social behaviour and before the introduction of British rule, it provided the unifying force in Sierra Leone by playing the role of the de facto government" (HARGREAVES 1956: 68). Hence, as it controlled virtually all forms of economic activities, it acted as the people's shield against colonial abuses. With its own judicial system, it addressed cases pertaining to witchcraft, murder, adultery, etc. It featured prominently during the Hut-Tax uprisings in 1897 and the protectorate disturbances of November 1955 to March $1956 .{ }^{6}$ For this and other reasons, the colonial authorities considered its activities insurrectionary. That was when it prohibited the harvesting of palm nuts. The move was regarded as a mortal threat to the very foundation of colonial rule in the country. Hence, the same authority considered a number of its practices that were part of the customs and traditions of the people as unbearably primitive. The society was proscribed in 1897 (see LITTLE 1965 for the history of Poro). ${ }^{7}$ Its abrogation is a clear manifestation of the colonial government's inability to know its limit as the association that, to all intents and purposes, governed Sierra Leone before the advent of foreign rule was not that of lawbreakers.

The Human Leopard Society comprised of ritual murderers with no educational purpose. As a sub-set of the Sierra Leone society, they were also members of the Poro Society, a social organisation whose aims were at variance with those of the former. As the colonial administrators have already, out of prejudice, resolved to paint all Africans with the same brush. They could not decipher the differences between the two groups, more so when the criminal organisation held its clandestine conventions in the Poro bush without permission.

Members of The Human Leopard Society have always been the prime suspects in any murder case in the community. Well-meaning members of society, including chiefs, endeavoured to get it exterminated. During an inquiry led by Sir D.P. Chamlers into an 1897 uprising, it was discovered that in 1880-1881 the chief of Tyama burnt nearly 100 members of the nefarious society. Another chief, Cardini also burnt a sub-chief and 80 other people for their membership (WRIGHT 1907:426). Other chiefs similarly adopted stringent measures, yet the society and its sister organisation, The Human Alligator Society, survived. However, the justice system, from the colonial authority's perspective, was barbaric and repugnant to

6 One of the wars of resistance fought against British colonialism in Sierra Leone led by Bai Bureh, a Temene chief.

7 For a more comprehensive account of the political function of the Poro (see LITTLE 1965; 1966).

DOI: 10.2478/eas-2018-0008 C University of SS. Cyril and Methodius in Trnava. All rights reserved. 
reason. On this ground, the local brand of justice was declared illegal as it could not be viewed with coldness.

With the traditional means of detecting the culprits abrogated, towards the end of 1894-1895, there was a murder bonanza for members of The Human Leopards Society. To tackle the development, in reaction to the endemic cries of the people, and the urgent need for an acceptable justice system, an extraordinary bill, The Human Leopards Ordinance of 1895 came into effect. The provisions of which, inter alia, made it penal for any person to possess any instrument identified with The Human Leopards Society and other allied organisations, and their membership was for the same reason declared illegal. In 1897, the hinterland of Sierra Leone became a protectorate (see WRIGHT 1907).

The proscribed society was in actuality a subterfuge to enhance a ritual medicine known as Borfima. It is considered to be a magic potion against all evil and supply all good. When its efficacy starts to wane, it requires reinvigoration, or a new one has to be prepared. Either option required human blood and fat. Hence, its procurement often necessitates murder, in which the members consume its parts. Habitually, it is old men and women, children and other less valuable members of society like the physically disabled and mentally retarded that are preferred victims. Marriot indicated that "When a visitor visits a village, he was invited to partake of food, in which was mixed a small quantity of human flesh. He will be eventually invited to join the society (MARRIOT 1899)." Influential members of the society offer their next of kin, even their own children, to further its course. Consequently, members commit murder to procure the relish for propitiating the Borfima.

The Colonial Office in London secured the services of the former Chief Justice of Gold Coast, Sir William Bradford Griffith, to preside over a special commission court set up by a clause of the aforementioned ordinance to try murder cases. He arrived in Sierra Leone on December 8, 1912 from England. Sir Griffith was of the opinion that "education and religion were needed to supply the place of the native crude beliefs" (see BEATTY Review by F.W.H.M. [1916]). On the face value, the suggestion seems plausible. However, among those convicted and subsequently publicly hanged for murder, were educated Christian clerks, traders, headmen, and chiefs of the towns as well as catechist and missionaries. A case in point was that of a well-read Christian missionary of The United Brethren in Christ Church, born in the United States. Beatty was of the view that "It was difficult to conceive how a man of his stamp could possibly be connected with a cannibal society, besides, he had allowed himself to be elected a paramount chief of one of the chiefdoms of the protectorate... that he acted in that capacity from 1899 to 1905 , connotes much" (BEATTY 1916). The colonial administrators found it incredible that those who had the advantage of prolonged residence 
and education in America and England and maintained impressive attendance at places of Christian worship also paid allegiance to The Human Leopards Society (see BURROW 1914).

Religion and education have not driven back these practices under consideration rather; the revitalised deep secrets are becoming abysmal. Though they appear to be waning in the predominantly Muslim parts of West Africa, they are however far from being over. Valentim Fernandes in the 1500s referred to the burial of wives and attendants in the grave of kings in the Mandingo country of The Gambia and among the Beafada of Guinea Bissau (LAW 1985:61). The advent of Islam superficially ended the practices. Nevertheless, there are still cases of nocturnal visits to cemeteries on the instructions of local consultant ritual medicine men, fashioning solutions to their clients wide range of problems that includes court cases. Also, educated indigenes still have a cause to travel to the Bambara country of Mali to consult ritualists and cultists traditionally believe to be more potent than those at home, in a predominantly Muslim country.

The Liberia Civil War disinterred the latent tendencies of a people who reverted to practices that were believed to have been confined to antiquity, in the officially recognized Christian republic. Despite the escalating number of educated men and women and the increasing sophistication of modern African states, the dead in cemeteries are not resting in peace. Other manifestations of the assertion are the theft of body parts from medical schools in order to use them for ritual medicinal purposes (see SCHOLTZ et. al 1979; STEYN 2005). Victims of communal feuds and, in some cases, family members, fall prey. Kidnappings of even newly born babies, unclaimed bodies in mortuaries, and afterbirths and shavings of women in labour in maternity wards in some instances disappear. Albinos and those with peculiar deformities such as hunchbacks are equally in demand in diverse places. The root cause is the abyssal secrets fuelling the unconscionable ambitions.

Marriot (1899) asserted that most secret societies of West Africa are tribal and with them are bound up the traditions and customs of the people, so their extinction would be impossible, though the modification appears in some cases desirable (see LITTLE 1949). The assertion is not entirely correct as he failed to acknowledge the difference between secret societies like The Poro and criminal gangs like The Human Leopard Society. The people of Sierra Leone were disgusted in multiple ways. That necessitated the application of the traditional justice system known to the Poro before the promulgation of the ordinance. If the activities of the illicit society were an integral part of the customs and traditions of the people of Sierra Leone, as Marriot probably want his readers to believe, it would have been futile for local initiatives to be set in motion to exterminate its members before the promulgation of the aforementioned 
ordinance. As stated earlier, "Research has led to the conclusion that the behavioural possibility or potentiality of cannibalism is entertained in all cultures. Isaac noted that cases of people bereft of a locally etched understanding of anthropophagy were yet to be encountered" (ISAAC 2002: 203). Hence, the claim of missionaries and colonial administrators that they were in Africa on civilizing mission is misleading.

Cannibalism as practiced by members of the proscribed Human Leopards Society is significantly different from what purportedly obtained among the Aztecs, Tupinamba and The Waris of Brazil and Iroquois. Consumers in the former case claim to derive magical powers from the act rather than securing the favour of a deity by eating the bodies (LAW 1985:58). The consumption of human flesh by some degenerates in Upper Guinea emanates from the faith in their Bofima. It had no connection with any deity, nor do they eat it to satisfy their appetite for food. In all parts of West Africa, where traits of these practices persist, there was no case of cultural or communal cannibalism i.e. that being part of culture, warfare, or social custom or religion of an entire people. The author knows of no West African society were identified perpetrators went Scot free. In pre-colonial and colonial Sierra Leone, for example, those in possession of 'bad medicine', such as the Borfima suffered excommunication, a move that was at variance with European impression. Europeans mistook execution of criminals and undesirables for human sacrifice. The same applies to burial customs, as they, Europeans, could not rationalize why the remains of the dead littered the environment.

Another spurious allegation is that African kings instigated wars designed to generate prisoners used for sacrifices and sold as commodities during the slave trade era. However, there is no fundamental distinction between African wars and the catastrophic European wars in history. These innumerable wars include The Napoleonic Wars, Crimea War, German and Italian Unification Wars, The Spanish Civil War, African Colonial Wars, the World Wars, Vietnam War, Korean War, etc. It should not be a surprise that African wars generated many prisoners, as they were less devastating than the latter. The destructive capability of European wars often results in abnormally high casualties. The case of the World Wars is an example. That partly explains why European wars did not generate as much war prisoners. ${ }^{8}$ Another reason is that Europeans maintained armies of occupation; therefore, there was no need to

8 The number of casualties recorded during the world wars is uncertain. However, the common estimates are WWI recorded over 16 million deaths and 20 million wounded while WWII recorded over 60 million deaths, over $2.5 \%$ of total world population making it the most catastrophic conflict in the history of mankind. 
cart away prisoners of war. That was not part of the defence strategies of African kingdoms and empires.

The practice of human sacrifice and cannibalism in any part of West Africa is as uncouth as similar practices in other parts of the world, where there is the booming illicit trade in kidney, liver, and other human organs, where it seems that only the perceptible cannibalism can be morally reprehensible. Blood transfusions and organ transplants either for medical research or for educational purposes, raw materials in industries as well as for foodstuff seem inoffensive. Despite the escalating tide of repugnance for the immoral use of human tissue, the political will to enforce legislation banning such practices is lacking. "The organ trafficking market is escalating worldwide. Numerous unfortunate stories of brokers, physicians, and hospitals engage in the illegal trade have featured in high profile media. The profitable enterprises facilitating the unregulated services exploit the poor in underdeveloped countries and offer substandard medical care with unacceptable outcomes to the rich recipients" (JAFAR 2009:1145). Furthermore, Lucas highlighted that during the Great European Famine of 1315, 1316 and 1317 in Livonia and Estonia, in the dioceses of Riga, Osel, Dorpat, and Reval, starving mothers ate their children and famishing men often died on the graves while digging up bodies for food. 'In addition,... in Slavic parts such as Poland and Silesia it appears that the famine and mortality still were common as late as 1319 and cannibalism is said to have been rife. The most revolting facts are recorded of what the starving did to relieve their hunger. Parents killed their children and children killed their parents, and the bodies of executed criminals were eagerly snatched from the gallows (LUCAS 1930:364, 376).

Colonial Africans did not understand the motives behind Europeans presence in Africa nor could they fathom their activities in other parts of the world. European history, according to Biber, is replete with stories of shipwreck (Maritime) cannibalism involving innumerable cases where lots were drawn to determine who will be eaten next, blood was drunk, the flesh was apportioned and bodily externalities (especially the head) were buried at sea (BIBER 2005 : 631). ${ }^{9}$ Crain Caleb (CALEB 1994:27-28) uncovered how cannibalism was resorted to among the survivors (seafarers) of The Nautilus (1807), The Essex (1820), The George (1822), The Francis Mary (1826), The Graincus (1828), The Dalusia (1833), The

9 See the cases of R v Dudley and Stephens (1884) 14 QBD 272 DC, R v Jamieson (1827) NSWSC 31; R v Lowe (1827) NSWSC 32, and U.S. v Holmes 26 F Case 360 (1842) for instances of some celebrated cases of maritime cannibalism.

DOI: 10.2478/eas-2018-0008 C University of SS. Cyril and Methodius in Trnava. All rights reserved. 
Lucy (1834), The Francis Spaight (1835), The Hannah (1836), and The Earl Moura (1838). Given up for dissection were anatomised bodies of hanged men. Also, were cases of human induced cannibalism in communist Russia and China that killed thousands of people (see VARDY - VARDY 2007). The survivors of the Uruguayan rugby team in 1972, after suffering an agonizing plane crash in the Andes Mountains, shared their gruesome experiences with reporters on television after their rescue. Sales (1957) explained how the peoples of the Near Eastern world in ancient times practiced human sacrifice, and the difficulties encountered by Bible writers in dissuading them from the habit. The Levantines had cause to revert to it a number of times even after it was replaced with animal sacrifice. The crucifixion of Christ (a man considered to be a criminal by the Jews) at Golgotha was a sacrifice that atoned for the iniquities of the world just like those performed in African societies for the atonement of sins. Forbes is of the opinion that state power wars like the Gulf War constitute a specific variety of human sacrifice, one which at first glance is described as secular, but which almost have a strong religious element. (FORBES 1995:61). During the age of exploration, survival instinct in hostile environments as the Arctic, compelled men of science to succumb to cannibalistic proclivities (see WESLAWSKI et. al. 2002; DUREY 2008).

\section{Contemporary issues}

The practice of cannibalism and human sacrifice in West Africa has been on the same trend with what obtained, and still prevails, in some other parts of the world. However, as it concerns the safety and security of lives, it is an issue that warrants special attention, more so, as it has spanned over the centuries. ${ }^{10}$ European colonialists used it as a tool to discredit indigenous people, the world over, to pave the way for eventual subjugation and economic exploitation. Also, it was a strategy used to avert blame for the genocidal wars that ushered in colonial conquest. It is a manifestation of European conspiracies and complicities of the coup d'états perpetrated against the non-European world during the era of imperialism, to

10 In the tenth century, Al- Bakir reported cases of female slaves buried with the king in Ghana Empire while Ibn Hawqal in the eleventh century confirmed the burial of servants in the royal grave. Ibn Battuta referred to Gobir in Hausa land where human sacrifice carried out at the funeral of the king, while Al Suyuti referred to substitutionary killing also in Gobir (see LAW 1985:61).

DOI: 10.2478/eas-2018-0008 C University of SS. Cyril and Methodius in Trnava. All rights reserved. 
topple legitimate regimes. Hence, they blew even shreds of cannibalism and human sacrifice out of proportion, to justify conquest and domination.

The problem outlived colonial rule, partly because Europeans interest in it centred on its threat to the attainment of colonial objectives. Colonial aims and aspirations would have been unattainable in the absence of peace and security. Despite the draconian measures taken in Sierra Leone (by the indigenes and colonialists) to curb cannibalism and ritual murder, the practices persisted. In the war against these practices, the involvement of indigenous structures like the Poro society would have been more productive. However, as Poro activities were contrary to British colonial interest, its proscription became imperative, especially when it prohibited its members from engaging in palm oil extraction, a principal source of oil to the British economy. The outlawing of Poro was ambiguous as traditional institutions played a key role during the implementation of the British colonial policy of indirect rule. Had the society not impede the colonial interests, it is likely that its presence would have been condoned. However, the colonial action undermined, in a number of ways, the structures and institutions that would have enhanced its interests.

African societies are becoming sophisticated owing to exposure to foreign ideas and customs, as well as refined indigenous thoughts, coupled with the accessibility to formal education. This has made the task of adequately addressing the problem under review more formidable. Rather than having a mitigating effect, Western education, as was noticed in colonial Sierra Leone, is compounding issues. An attestation is that the educated, indeed in some cases, men of letters who are in search of power, position, and wealth are neck deep in ritual activities, particularly murder. They constitute a formidable set of those with the appropriate connections and influence to pervert the course of justice. Besides, they have the expertise and power which the unlettered lack.

Political power in West African states is concentrated in the hands of politicians, a subset of society reputed for their inordinate ambitions. In addition, they have in virtually all cases failed to live up to public expectation. An incident in colonial Gold Coast, now Republic of Ghana, attest to what still prevail among those in search of power:

On Monday, March 19, 1945 during the morning hours, the body of a young girl of ten was found on the beach, a short distance from the town of Elmina. According to the coroner, she had been dead for between 24 and 48 hours. There was no water in her lungs or stomach, which indicated that she had not died by drowning. Instead, her upper and lower lips, both cheeks, eyes, her private parts and anus, and several elliptical pieces of skin from different parts of her body had been removed. Many of these wounds exposed large blood vessels and the coroner concluded that 'death was due to shock and haemorrhage.' The corpse was 
identified as Ama Krakraba. She had been missing since the evening of Saturday, March7. Her frantic mother had immediately suspected foul play and had confronted Kweku Ewusie, the Regent of the Edina State, who was later accused of having 'enticed' the young girl to the third floor of Bridge House, where he lived, 'by the ruse of sending her out on an errand to buy tobacco'.' There she had been murdered so that her body parts could be used to make 'medicine' to help the Regent's faction win a court case that was critical for their political standing in Elmina. On March 24, after a preliminary investigation, the colony's attorneygeneral brought charges of murder against Kweku Ewusie and four others from Elmina: Joe Smith, Herbert Krakue, Nana Appram Esson, alias Joseph Bracton Johnson, and Akodei Mensah. They were tried at the Accra Criminal Assizes from May 6 to June 2, found guilty of first degree murder, and sentenced to be hanged. The West African Court of Appeal turned down their appeal on June 28, 1945 as did the Privy Council on January 14, 1946. On February 1, I946, Kweku Ewusie, Joe Smith and Herbert Krakue were hanged at James Fort in Accra, and on February 2, J. B. Johnson and Akodei Mensah suffered the same fate....All of the five accused were at least nominally Christians. One was a practicing Catholic who had supposedly received Holy Communion the morning before the murder was committed. After their execution in I946, the bodies were buried in either the Catholic or Methodist sections of the Accra public cemetery (GOCKING 2000: 179, 200-201).

There is hardly a month in Ghana whereby the local news media does not report at least a case of ritual murder somewhere in the country. Stories of the nature narrated below often appear to be stale news to members of the public due to its rate of recurrence:

Three women were murdered at Kissi and Besease in the Komenda Edina Eguafo Abirem Municipality of the Central Region in what police suspect to be ritual murders. The women were slashed and their private parts had also been taken away. The gory incidents have left residents in the two towns in utter shock and are calling for adequate security to avert future occurrence. Richard Kwadwo Nyarku visited the community and reported that the decomposed body of the first woman was immediately buried after her body was found. Twelve hours after that discovery, a second woman in her mid-twenties was found dead with machete wounds all over her body. The third was also found ten hours after the discovery of the second victim. She was found dead in a pool of blood with her female sex organ and some internal organs severed. Richard Kwadwo Nyarku noted that: "these events have left a sour taste in the mouth of residents in the Kissi and Besease townships. The youth and women of the two communities who are highly traumatised are in red arm bands". Isaac Dominic Sawyer, an Assembly Member for the Kissi West Electoral Area, told Joy News they had reported the incidents to the police. Isaac Kweku Sam, Municipal Chief Executive and Head of the Komenda Edina Eguafo Abirem Security Council, has asked for total co-operation of 
residents to help the police find the perpetrators of the dreadful crimes. The bodies of the two women have been deposited in the Central Regional Hospital morgue while various search parties have been commissioned by the two communities to support efforts of the police to bring the culprits to book. ${ }^{11}$

It is challenging to ascertain if the problem is either waxing stronger or waning. 'In 1979, some prominent figures of the ruling True Whig Party in the Maryland County of Liberia were convicted for committing a ritual murder. Ten years later, Liberian Defence Minister Gray Allison was guilty of, and subsequently convicted for killing a police officer apparently used in a ritual sacrifice. The government at the time displayed blood drained in gallons believed to be that of the dead man. This was at a time when a spate of ritual murders was reported' (ELLIS 1995:190). ${ }^{12}$

On the first anniversary of the 1980 coup in Liberia, President Samuel Doe erected a monument on the road outside i.e. Executive Mansion, one of the main arteries of Monrovia, known as the Tomb of the Unknown Soldier. The monument consists of a plinth displaying an inscription commemorating the liberation of Liberia, by soldiers of the AFL, ${ }^{13}$ from decades of government by what is termed a 'clique', meaning the American-Liberian elite of the True Whig Party. On top of the plinth is a statue of an AFL soldier with rifle at the ready, bayonet fixed. Monrovians are convinced that Doe inaugurated the statue with a human sacrifice, burying alive an AFL trooper beneath it. True or not and it would certainly be in

11 Source: Daily Guide Ghana:

The following headlines appeared in various Ghana newspapers between 2012 and 2013:

Ritual murder scares residents of Bekpo in Volta region

March 27, 2013

Ritual killings hit Wassa Japa

July 24, 2012

Four people murdered in bizarre manner Agona Nkwanta

May 28, 2013

Woman's dead body found near Rawlings' House

May 24, 2012

Woman found dead with breasts, genitals and other body parts...

Aug. 13, 2012

Hunchback Woman killed for Sakawa at Akwatia

May 29, 2013

Ekumfi Chief, Nana Eguase head recovered

June 11, 2012

Four Murdered in Bizarre manner

May 28, 2013

Fante King Nana Kojo Agyase beheaded

June 8, 2012

Naked Woman found dead at Dome.

Feb 10, 2012

12 See http://www.globalpost.com/dispatch/news/regions/africa/110728/ritual-killing-liberia-Electionpolitics.

13 Armed Forces of Liberia.

DOI: 10.2478/eas-2018-0008 C University of SS. Cyril and Methodius in Trnava. All rights reserved. 
keeping with what is known of Doe's methods to have taken such a precaution many Monrovians are convinced that this was the case. When, in 1990, NPFL $^{14}$ forces had invested the University of Liberia, a few hundred yards from the Executive Mansion, where Doe was besieged with hundreds of his soldiers, the NPFL fighters believed that the statue which stood in the no man's land between themselves and Doe's men in the Executive Mansion constituted a powerful magical protection for Doe and that he could never be defeated while it stood. The military under Doe generally cultivated what Sawyer ${ }^{15}$ refers to as a 'magicosupernaturalism', believing that their possession of the powerful technology of modern warfare endowed them with spiritual power. So great was Doe's reputation for cultivating occult forces that his suite of rooms in the Executive Mansion remained sealed and undisturbed even after the IGNU had occupied the building in 1990. The Mansion was, in a manner of speaking, haunted by the terrible spirits, which Doe had invoked in the years that he lived there. (ELLIS 1995: 190-191).

In Liberia's Maryland County, Fulton Yancy, the county legal attorney, along with a former senatorial candidate, Dan Morias, were among those tried in 2009, for the ritual murder of a pregnant woman... Ironically, in the 1970s, Fulton Yancy's elder brother, legislator Allen Yancy, and seven others were executed for committing ritual murder. Also in 2009, Liberian President Johnson Sirleaf warned Maryland County citizens against seeking retribution for killings with a traditional practice of trial by ordeal, a custom she outlawed in 2007 on assuming office (SCHMALL - WILLIAMS 2011). The alarming eruption, which shocked the world, of gruesome pictures of cannibalistic activities during the Liberia and Sierra Leone civil wars of the nineties connote much. The breakdown of law and order during the mayhems resuscitated the public manifestation of the apparently long forgotten latent capability of the practitioners. It will be demanding to determine the degree to which these ingrained practices have been perpetrated behind the scene before the outbreak of hostilities. The ease with which their practitioners went about their cadaverous business, especially the uniform modus operandi and tenacity across the country, at the height of the war indicate that the deeds, which were not alien to them, must have been going on clandestinely before the outbreak of hostilities. Throughout the length and breadth of both countries, the slogan was that strength and protection were acquired by eating the hearts of strong men (warriors). It is amazing that

14 National Patriotic Forces of Liberia, the rebel movement led by Charles Taylor in his bid to oust the Liberian president, Samuel K. Doe from office.

15 Interim president of Liberia, head of the Interim Government of National Unity (IGNU).

DOI: 10.2478/eas-2018-0008 C University of SS. Cyril and Methodius in Trnava. All rights reserved. 
such horrendous deeds persisted across generations, yet concealed from public view, though there were occasional arrests by law enforcement officers:

Rumours of child kidnappings had been circulating in Owerri, the capital of Imo State in south-eastern Nigeria, for more than a year. One Saturday night in September 1996, a local television station broadcast pictures of a man holding the freshly severed head of a child. The video was accompanied by an announcement that the man with the head had been arrested the previous day. The police did not know the identity of the child and were asking for the public's assistance. Early Sunday morning, the alleged perpetrator died mysteriously in jail. On Monday, the news of the man's death in police custody began to circulate in Owerri. Tuesday morning, a police team moved to the premises of Otokoto Hotel, a popular lodge in town where the alleged murderer had worked. That morning, police unearthed the headless body of the boy from the hotel grounds. A large gathering grew as the police worked. When the police team left the scene with the boy's body, having first arrested the hotel owner and all of the hotel's staff, the crowd became an angry mob. The irate throng burned the buildings and vehicles in the Otokoto Hotel premises. They then moved across the street to burn an upscale supermarket catering to Owerri's elite. From there, the crowd grew still larger and moved across the city burning many of Owerri's most select stores and hotels. In addition, the crowd burned the palace of one of the traditional chiefs of Owerri, as well as the houses of other wealthy men.... The rioting and burning continued into Wednesday, sparked by the alleged discovery the next morning of a roasted human corpse at the residence of Damaco, one of Owerri's young millionaires. In addition, word spread of the purported finding of human skulls and human meat, pepper soup (implying a practice of ritual cannibalism) at the Overcomers Christian Mission, the Pentecostal church where Damaco worshipped. More than 25 buildings and dozens of vehicles were torched before the riots subsided. The cessation of violence was due in part to a strict curfew imposed on the town by Nigeria's military government (SMITH 2001:803)

\section{Conclusion}

Diverse motives, mentioned in this article, have fuelled the proliferation of cases of cannibalism and allied practices in various parts of the sub region. This is in line with what prevails, in various guises, in some other parts of the world. It is rational to assume that eradicating them will be virtually impossible in a life time. This write up has shown that even the highly educated and those who maintained impressive records of attendance in places of Christian worship, as well as the rich, and members of the political class, are also implicated. 
Experiences have shown that most of them, particularly those of the political class, are virtually above the law. Incontrovertibly, education and the Christian religion have explicitly failed in this regard in achieving their objectives.

In Nigeria, the nauseating activities of secret societies expressly affect civil society in general. During the ephemeral reign of General Murtala Mohammed from July 29, 1975 until February 13, 1976, the federal government had cause to outlaw the membership of all such fraternities in the federation, as their reprehensible activities were intolerable. The proscribed groups have over time resurfaced in other facades with perceptibly unrefined goals. Some of their appalling deeds perpetrated by cultists portrayed in Nigerian (Nollywood) movies, though imaginary, depict anthropologically candid events generally believed to be in vogue. Universities are also infested with secret cults whose members (lecturers and students), are known to be nocturnal visitors to cemeteries. These institutions of higher learning have become the nurseries for milling and churning out cultists and 'ritualists' in society upon their graduation. The graves of important people in some places are diligently guarded, long after burial, for fear of ritual medicine men desecrating them in search of human parts. A popular belief has it that using the parts of such personalities to concoct ritual medicines will enhance its efficacy. It is also held that it would enable the owner of such medicines to acquire the qualities that the deceased once possessed.

Some mortuaries are fertile grounds for illicit human organ supply for rituals. The law relating to dead bodies in Nigeria, according to Nwabueze, is ill defined. He attributed this to mistaken identification and swapping of bodies in mortuaries, an indication that all is not truly well with the dead in the country (NWABUEZE 2007:117).

Certain practices, connected with the burial and coronation of traditional rulers are illegal in the whole of West Africa, at least officially. Consequently, animals have been substituted for human sacrifice in all known cases. That is the official position. However, as members of the public are in the dark regarding what transpires during either a royal obituary or coronation ceremony, it is hard to tell what really ensues behind the scene. There are still talks of covert objectionable deeds being perpetrated. In addition, deceased members of some royal families are, by tradition, not interred outside their ancestral homes. Cases of excruciating difficulties being tolerated while retrieving some corpses from distant parts of the earth are not rare. It is demanding to tell what happens to such bodies in obscurity. In his autobiography Ake, years of childhood, Wole Soyinka explained how prospective kings, during their coronation, feed on the heart of their immediate predecessor, as a requirement for enthronement.

As reform is not new in the social, cultural milieu of the sub region, there is need for governments to show refined interest in what prevails during royal burials and coronation 
ceremonies. Confidentiality should still be guaranteed but with government representation in all aspects of various activities, more so when the upkeep of the traditional institutions rests squarely on taxpayer's money. Any form of intransigence on the part of the royal families should attract penal sanctions, as no facet of the customs and traditions of a people should be immune to change.

Article 3, section 111 of the Economic Community of West Africa Treaty emphasized the removal, between member states of obstacles to free movement of persons, goods, services and capital and the right of residence and establishment. Its implementation could equip and expedite criminal gangs with easy access to travel and other documents. The security checks at embassies, preceding the issuance of visas and other travel permits, before travelling within the sub region are no longer in force. This could escalate cases of human trafficking, a lucrative source of illicit human organs. As the rules regulating residency are relaxed, previously uninfected areas could be prone to risk. Hitherto there seems to be no effective means of keeping track of people's movements due to the absence of national identification schemes in some member states let alone a synchronized regional scheme. As long as this situation prevails, unclaimed bodies in mortuaries will remain vulnerable, as a few countries, if any, maintain registers of missing persons. The French President Nicholas Sarkozey in 2007, on a mission to N'djamena, the Chadian capital, secured the release of three French men and seven Spanish flight attendants, a group of self-styled relief workers, apprehended by government officials in Chad on the verge of transporting 103 African children by air to Europe. The motive of the ill-fated trip has remained mysterious. ${ }^{16}$

Furthermore, closely associated with human sacrifice is the traditional post-mortem examination of corpses for witchcraft potentials. There is the belief, though not widespread, that a wicked man becomes intensely wicked in death if the witchcraft potential in him remains intact before interment. Consequently, this has necessitated the scrutiny of some vital organs, such as the liver, before interment. Moreover, there have been cases of widows, compelled against their will, to drink of the bath water used of their deceased husbands. This 
is designed to clear them of suspicion of complicity in the cause his demise. There is a need for practices of these natures to be made penal as they are repugnant to reason.

However, legislation similar to the failure of education and Christianity, will not address these problems if the laws are either unenforceable or the collective will to do so is lacking. The limited success achieved by the colonial administration in Sierra Leone was to the credit of the indigenes who furnished District Officers with information. Matters of this nature require the collective involvement of the citizenry in collaboration with law enforcement agencies. However, the penal codes of all West African states are modelled on European legal systems; hence they are of colonial origin. Besides, most of them are yet to be adequately reformed. This explains why stipulated penalties for the deeds are not commensurate with the gravity of the atrocities. In Nigeria for instance, the Police Act of 1930 is a product of the colonial authorities which still form the basis of policing the entire country. From the look of things, the political will to reform it, to cater for modern realities, is lacking. The entire police force remains a principal culprit in perpetuating crimes in the country as it is widely whispered that virtually all its members are, in one way or the other, hand in glove with lawbreakers in both high and low places.

Additionally, the popular belief connecting cannibalism, ritual murder and allied practices on one hand with the inordinate acquisition of wealth and power on the other, is waxing stronger. Conversely, the efficacy of government apparatus for tackling the threats to individual and public safety and security is waning. Also, in reaction to complaints from enrage members of the public; the definitive reaction of government does not go beyond the issuance of policy statements after a hearing of a commission of inquiry. Rather than involving members of the public through collective responsibility, the use of lethal force by the police and military, and increasing their number if necessary, are the only weapons in government's arsenal. This has made the identification of the practitioners of acts and their collaborators, especially in time of peace knotty. The situation has been exacerbated by the steady evolution of the individualistic and materialistic nature the society assumed since the advent of colonialism. An outcome of which is the belief that it is better to die trying to get rich than to die in poverty. These have, in no small measure, eroded age long cultural values that were ingrained in high ethical standards.

Lastly, in the light of the global magnitude of black markets fuelling the human organ commerce, as long as the sub region remains an integral part of what is now referred to as the global village, the end to the predicament is evidently not in sight. 


\section{Bibliography}

ABLER, Thomas S. (1980): Iroquois Cannibalism: Fact Not Fiction. In Ethno History Vol. 27, No. 4, Special Iroquois Issue, pp. 309-316.

ARENS, William (1979): The Man Eating Myth. Anthropology \& Anthropophagy. Oxford: O.U.P.

BURROWS, D. (1914): The Human Leopard of Sierra Leone. In Journal of the Royal African Society, Vol. 3, No. 50, pp. 143-151.

BEATTY, Kenneth James (1915): Human Leopards: An account of the Trials of Human Leopards before the Special Commission Courts; with a note on Sierra Leone, Past and Present. London: Hugh Rees.

BEATTY, Kenneth James (1916): Review by F.W.H.M. Human Leopards Society. In Journal of the Royal African Society, Vol.15, No.59, pp. 290-292.

BIBER, Katherine (2005): Cannibals and Colonialism. (Seminar paper delivered at Macquarie University, Department of Anthropology). In Sydney Law Review, Vol. 27, pp. 623-637.

BINFORD, Lewis R. (1981): Bones: Ancient Men and Modern Myths. New York: Academic Press.

BARDY, Ivan. (1982): The Myth-Eating Man. In American Anthropologist, Vol.84, pp. 595-611.

CALEB Crain (1994): Lovers of Human Flesh: Homosexuality and Cannibalism in Melville's Novels. American Literature, Vol. 66, No. 1, New Melville. pp. 25-53.

CERUTI, Maria Constazna (2004): Human Bodies as Objects of Dedication at Inca Mountain Shrines (North-Western Argentina). In World Archaeology, Vol. 36, No. 1, pp. 103-122.

CONKLIN, Beth. A. (1997): Consuming Images: Representations of Cannibalism on the Amazon Frontier. In Anthropological Quarterly, Vol. 70, No. 2, pp. 68-78.

CRAIN, Caleb (1994): Lovers of Human Flesh: Homosexuality and Cannibalism in Melville's Novels. In American Literature, Vol. 66, No. 1, pp 25-53.

DUREY, Michael (2008): Exploration at the Edge: Reassessing the Fate of Sir John Franklin's Last Arctic Expedition. In The Great Circle, Vol. 30, No. 2. Pp. 3-40.

ELLIS, Stephen (1995): Liberia 1989-1994: A Study of Ethnic and Spiritual Violence. In African Affairs, Vol. 94, No. 375, pp. 165-197. 
ELLIS, Stephen (2001): Mystical Weapons: Some Evidence from Liberian War. In Journal of Religion in Africa, Vol. 31, Facs 2, Religion and War in the1990s, pp. 222 236.

FORBES, Jack. D. (1995): The Gulf War: Once Again the Dream of Human Sacrifice. In Wicazosa Review, Vol. 11, No 1, pp. 60-62.

GOCKING, ROGER A. (2000): Chieftaincy Dispute and Ritual Murder in Elmina, Ghana, 1945-6. In The Journal of African History, Vol. 41, No. 2, pp. 197-219.

GOLDMAN, Laurence. (1999): From Pot to Polemic: Uses and Abuses of Cannibalism. In Anthropology of Cannibalism, Bergin and Garvey, West Point Connecticut, pp.1-26, at 14 .

GRAHAM, James D. (1965): The Slave Trade, Depopulation and Human Sacrifice in Benin History. In Cahiers d' Etudes Africaines, Vol. 5, No. 18, pp. 312-344.

GRAULICH, Michel (2000): Aztec Human Sacrifice as Expiation. In History of Religions, Vol. 39, No. 4, pp. 352-371.

HARNER, Michael (1977): The Ecological Basis for Aztec Sacrifice. In American Ethnologist, Vol. 4, No. 1, Human Ecology, pp. 117-135.

HARGREAVES, John D. (1956): The Establishment of the Sierra Leone Protectorate and the Insurrection of 1898. In Cambridge Historical Journal, Vol. 12, No. 1, pp. 56-80.

ISAAC, Barry L. (2002): Cannibalism among the Aztecs and their Neighbours: Analysis of the 1577-1586 "Relaciones Geográficas" for Nueva España and Nueva Galicia Provinces. In Journal of Anthropological Research, Vol. 58, No. 2, pp. 203-224.

JAFAR, Tazeen H. (2009): Organ Trafficking: Global Solutions for a Global Problem. In American Journal of Kidney Diseases, Vol. 54, No. 6, pp. 1145-1157.

KRAAN, Alfons van der (1985): Human Sacrifice in Bali: Sources, Notes, and Commentary. In Indonesia, Vol. 40, pp. 89-121.

LINDENBAUM, Shirley (2004): Thinking about Cannibalism. In American Review of Anthropology, Vol. 33, pp. 475-495.

LITTLE, Kenneth. (1949): The Role of the Secret Society in Cultural Specialization. In American Anthropologist, New Series, Vol. 51, No. 2, pp. 199-212.

LITTLE, Kenneth (1965): The Political Function of the Poro. Part 1. In Journal of the International African Institute, Vol. 35, No. 4, pp. 340-365.

LITTLE, Kenneth (1966): The Political Function of the Poro. Part 2. In Journal of the International African Institute, Vol. 36, No. 1, pp. 62-72. 
LUCAS, HENRY S. (1930): The Great European Famine of 1315, 1316, and 1317. In Speculum. A Journal of Medieval Studies 1930, Vol. 5, No. 4, pp. 343-377.

LAW, ROBIN (1985): Human Sacrifice in Pre-Colonial West Africa. In African Affairs, Vol. 84, No. 334, pp. 53-87.

MARRIOT, Fitzgerald H. P. (1899): The Secret Societies of West Africa. In The Journal of Anthropological Institute of Great Britain and Ireland, Vol. 29, No. 1/2, pp. 21-27.

NWABUEZE, Remigius N. (2007): Dead Bodies in Nigerian Jurisprudence. In Journal of African Law, Vol. 51, No. 1, pp. 117-150.

ORTIZ DE MONTELLANO, Bernard R. (1978): Aztec Cannibalism: An Ecological Necessity? In Science, New Series, Vol. 20, No. 4342, pp. 611-617.

SALES, R. H. (1957): Human Sacrifice in Biblical Thought. In Journal of Bible and Religion, Vol. 25, pp. 112-117.

SAMPER, David. (2002): Cannibalizing Kids: Rumour and Resistance in Latin America. In Journal of Folklore Research, Vol. 39, No. 1, pp. 1-33.

SCHMALL, Emily; WILLIAMS Wade. (2011): Liberia's Elections, Ritual Killings and Cannibalism. In America World News, Global Post (https://www.pri.org/stories/2011-0801/liberia-s-elections-ritual-killings-and-cannibalism).

SCHOLTZ, H. J., Phillips V. M, Knobel G. J. (1997): Muti or Ritual Murder. In Forensic Science International, Vol. 87 (2) pp. 117-123.

SMITH, Daniel Jordan (2001): Ritual Killing, 419, and Fast Wealth: Inequality and the Popular Imagination in South-eastern Nigeria. In Ethnologist, Vol. 28, No. 4, pp. 803823.

STEYN, Maryna. (2005): Muti Murders from South Africa: A Case Report. In Forensic Science International, Vol. 151, pp. 279-287.

THOMAS, Northcote Whitridge (1920): Notes on Edo Burial Customs. In The Journal of the Royal Anthropological Institute of Great Britain and Ireland, Vol. 50, pp. 377-411.

TURNER, Christy. G. - TURNER, Jacqueline A. (1992): The First Claim for Cannibalism in the South West: Walter Hough's1901 Discovery at Canyon Butte Ruin 3, Northwestern Arizona. In American Antitiq, Vol. 57, No. 4, pp. 661-682.

VARDY, Steven Bela - VARDY Agnes Huszar (2007): Cannibalism in Stalin's Russia and Mao's China. In East European Quarterly, XLI, No 2. pp 223-238

VILLA, Paola. (1992): Cannibalism in Prehistoric Europe. In Evolutionary Anthropology, Vol. 1, No 3. pp. 93-104. 
WESLAWSKI, Jan Marcin - LEGEZYNSKA Joanna (2002): Chances for Arctic Survival: Greely's Expedition Revisited. In Arctic, Vol. 55, No. 4, pp. 373-379.

WHITE, Tim D. (1992): Prehistoric Cannibalism at Mancos. Princeton, NJ: Princeton University Press.

WHITEHEAD, Neil (1984): Carib Cannibalism: The Historical Evidence. In Journal de la société des Américanistes, Vol. 70. pp. 69-88.

WILKS, Ivor. (1988): Asante: Human Sacrifice or Capital Punishment? A rejoinder. In The International Journal of African Historical Studies, Vol, 21, No. 3, pp. 433-452.

WILLIAMS, Clifford (1988): Asantee: Human sacrifice or Capital Punishment? An Assessment of the period 1807-1874. In The Journal of African Historical Studies, Vol. 21 , No. 3, pp. 433-441.

WILSON, Horace Hayman (1852): On the Sacrifice of Human Beings as an Element of Ancient Religion of India. In Journal of the Royal Asiatic Society of Great Britain and Ireland, Vol. 13, pp. 96-107.

WHITEHEAD, A. A. (1905): African Fetish. In Journal of the Royal African Society, Vol. 4, No. 16 , pp. 410-416.

WINKELMAN, Michael (1998): Aztec Human Sacrifice: Cross cultural Assessments of the Ecological Hypothesis. In Ethnology, Vol. 37, No. 3, pp. 285-298.

WRIGHT, A. R. (1907): Secret Societies and Fetishism in Sierra Leone. In Folklore, Vol. 18 , No. 4, pp. 423-427. 